\title{
A comparative ecophysiological study of two infaunal filter-feeding bivalves: Paphia rhomboïdes and Glycymeris glycymeris
}

\author{
Marie Savina $^{\mathrm{a}}$ and Stéphane Pouvreau ${ }^{\mathrm{b}}$ \\ a : Laboratoire "Biodiversité Benthique", Centre IFREMER de Brest BP 70, 29280 Plouzané, France \\ b : Laboratoire "Physiologie et Écophysiologie des Mollusques Marins", Station IFREMER d'Argenton, Presqu'île \\ du Vivier, 29840 Argenton, France
}

*: Corresponding author : email address : spouvrea@ifremer, phone number : 0298895332 - fax number : 0298895777

\begin{abstract}
:
A comparative ecophysiological study was carried out in September and November 2002 for two bivalves, Paphia rhomboïdes and Glycymeris glycymeris, which are significantly harvested in the Western Channel (French coast). Individual measurements of clearance and respiration rates were performed for both species, in several experimental conditions of temperature and phytoplankton concentrations. Those conditions were chosen to be in the range of those commonly observed in the subtidal area of the Western Channel. The mean value of clearance rate and oxygen consumption obtained from continuous data recording did not reveal any significant influence of temperature in the investigated range, but a significant difference between $P$. rhomboïdes and $G$. glycymeris.
\end{abstract}

P. rhomboïdes showed a continuous feeding activity and faeces production and was characterised by high clearance rate (mean=1.7 $\mathrm{h}^{-1} \mathrm{~g}^{-1}$ ) regulated by the phytoplankton concentration and high assimilation efficiency (approximately 90\%). On the opposite, G. glycymeris showed a periodic feeding activity and faeces production with low clearance rates independent of phytoplankton concentration (mean $=0.4 \mathrm{I} \mathrm{h}^{-1} \mathrm{~g}^{-1}$ ) and a lower assimilation efficiency (approximately $78 \%$ ). Individual SFG values were calculated for both species and it appears that $P$. rhomboïdes exhibited higher SFG values than G. glycymeris, except for low concentration of algae. These results may help to explain the significant difference in growth rate of both species. However, assumptions are made on differences in food source and/or feeding behaviour of $P$. rhomboïdes and G. glycymeris 


\section{Abstract}

A comparative ecophysiological study was carried out in September and November 2002 for two bivalves, Paphia rhomboïdes and Glycymeris glycymeris, which are significantly harvested in the Western Channel (French coast). Individual measurements of clearance and respiration rates were performed for both species, in several experimental conditions of temperature and phytoplankton concentrations. Those conditions were chosen to be in the range of those commonly observed in the subtidal area of the Western Channel. The mean value of clearance rate and oxygen consumption obtained from continuous data recording did not reveal any significant influence of temperature in the investigated range, but a significant difference between P. rhomboïdes and G. glycymeris.

P. rhomboïdes showed a continuous feeding activity and faeces production and was characterised by high clearance rate (mean : $1.7 \mathrm{l} \cdot \mathrm{h}^{-1} \cdot \mathrm{g}^{-1}$ ) regulated by the phytoplankton concentration and high assimilation efficiency (approx. 90\%). On the opposite, G. glycymeris showed a periodic feeding activity and faeces production with low clearance rates independent of phytoplankton concentration (mean: $0.41 . \mathrm{h}^{-1} \cdot \mathrm{g}^{-1}$ ) and a lower assimilation efficiency (approx. 78\%). Individual SFG values were calculated for both species and it appears that $P$. rhomboïdes exhibited higher SFG values than $G$. glycymeris, except for low concentration of algae. These results may help to explain the significant difference in growth rate of both species. However, assumptions are made on differences in food source and/or feeding behaviour of Paphia and Glycymeris.

\section{Keywords}

Ecophysiology, scope for growth, Paphia rhomboïdes, Glycymeris glycymeris, bivalves, filterfeeding 


\section{Introduction}

The "Normand-Breton" gulf, located in front of the French coast of the Western channel (from the Bay of Saint-Brieuc to the Channel island area), is a highly exploited marine area. Fisheries of scallops Pecten maximus (3000 T in 2002) and clams Venus verrucosa (400 T in 2002) traditionally exist and since 1985-1986 important fisheries of banded carpet shells Paphia rhomboïdes (800 T in 2002) and dog cockles Glycymeris glycymeris (3200 T in 2002) have increased in importance. An ecological model is currently being developed in order to understand the repartition of the latter species in the English Channel, particularly in 'Normand-Breton' gulf and to contribute to their fisheries management.

Nevertheless, data on both species are very scarce and dissipated, and knowledge remains quite limited. G. glycymeris and P. rhomboïdes are subtidal, infaunal and filter-feeding bivalves, widely distributed in this area (Holmes, 1966; Retière, 1979; Noël et al., 1995), where they often coexist in the same habitat and represent up to more than $80 \%$ of the total biomass (Retière, 1979). Both species live in coarse sediments, with nearly no silt and high bottom currents (Holmes, 1966; Cabioch, 1968; Retière, 1979). But their growth rates are quite different: P. rhomboïdes live up to 12 years with a high growth rate (Von Bertalanffy parameter $\mathrm{k}=0.8$, unpublished data) during the first three years, whereas G. glycymeris is a long-lived species around 25 years (Morvan, 1987; Noël et al., 1995) with a low growth rate (Von Bertalanffy parameter k=0.15, unpublished data) during the first 10 years and no significant growth there after. In some cases, it has been shown that some individuals can reach 70 years (Steingrimsson, 1989) and even 101 years (Ramsay et al., 2000) around the Isle of Man.

From a bio-energetic point of view, such differences between two filter feeders inhabiting the same biotope look paradoxical. Since no ecophysiological data are available on these two bivalves for the hydrobiological conditions of the "Normand-Breton" gulf, it remains impossible to explain this 
difference in growth. This lack of knowledge is particularly impairing for a deterministic modelling approach. Consequently, the aim of the present work was to compare, in the same conditions, the main ecophysiological function of $P$. rhomboïdes and G. glycymeris (time activity, clearance rate, absorption efficiency and oxygen consumption) and calculate a scope for growth for both species. 


\section{Material and methods}

\subsection{Biological material and acclimation procedure}

Samples of both species (P. rhomboïdes and G. glycymeris) were collected in the Bay of SaintBrieuc where they were trawled by the "Shamrock" (shellfish bottom trawler) at the beginning of September 2002. Before being used for ecophysiological experimentation, they were held in openflow tanks in the IFREMER Shellfish Laboratory located near Argenton (France). Tanks were supplied with seawater pumped at mid-depth in the tidal dock of the laboratory. The condition mimicked the Bay of Saint-Brieuc environment encountered in September: temperature, salinity and oxygen content were kept constant at $16^{\circ} \mathrm{C}, 35 \%$ and 7-8 $\mathrm{mgO}_{2} \cdot \mathrm{l}^{-1}$. Phytoplankton concentration was maintained at approximately $5 \mu \mathrm{g} . \mathrm{l}^{-1} \mathrm{chl} a$ by feeding bivalves with a mixture of 4 cultivated micro-algae (Table 1). One week before experimentation, the bivalves were progressively acclimated to the appropriate temperature.

\subsection{Ecophysiological measurement system}

The IFREMER Shellfish laboratory of Argenton is fitted with an ecophysiological system, which allows the simultaneous monitoring of the clearance rate $\left(\mathrm{CR}, 1 . \mathrm{h}^{-1}\right)$ and oxygen consumption rate $\left(\mathrm{R}, \mathrm{mgO}_{2} \cdot \mathrm{h}^{-1}\right)$ in individual open-flow chambers, for 6 individuals. Furthermore, the system allows the collection of biodeposits at the end of the measure in order to estimate the absorption efficiency of the diet (AE, \%).

The experimental apparatus is briefly described in Fig. 1. The system is made of 8 individual openflow Plexiglas chambers (volume 1.2 l), two chambers being used as a control (without bivalve). A baffle in each chamber prevents the recirculation of once filtered water (Fig. 1b). Upstream, the seawater is filtered, thermo-regulated, and enriched with cultivated algae at a fixed concentration by a peristaltic pump. The flow rate across the chamber can be controlled by means of a manual flow meter. The algal and oxygen concentrations were monitored alternatively in the water leaving each 
chamber, by means of an oxymeter (WTW sensor) and a fluorimeter (Seapoint sensor), a system of floodgates allowed us to choose the measured chamber. Data collected by the two sensors were sent to an Ethernet data acquisition system (Fieldpoint module, National Instruments Corp., 93153 Le Blanc Mesnil, France), itself connected to a computer via the local network.

\subsection{Experimental conditions}

A total of 15 experiments (of around 24 h. each) were conducted from October to December 2002 in order to obtain ecophysiological measurements for several representative hydrobiological conditions. In the subtidal areas of the "Normand-Breton" gulf, temperature and phytoplankton concentration usually vary, respectively, from 8 to $18^{\circ} \mathrm{C}$ and from 1 to $15 \mu \mathrm{g} . \mathrm{l}^{-1} \mathrm{chl} a$ (Hoch, 1998). Consequently, the experimental conditions were chosen to cover the range of values encountered in the bay. Due to technical problem, the lower temperatures could not be tested $\left(8-10{ }^{\circ} \mathrm{C}\right)$.

\subsection{Ecophysiological measurement procedure}

Each time, experiments were performed simultaneously with three $P$. rhomboïdes and three $G$. glycymeris. Individuals were placed, successively, in one of the eight individual chambers of the system and kept undisturbed in their respective chamber for at least $24 \mathrm{~h}$. The first and last chamber were kept empty and used as controls. Flow rates in the individual chambers were constant and equal to $41 \mathrm{ml} \cdot \mathrm{min}^{-1}$. This value was chosen after a series of tests : the flow rate had to be low enough to allow us to detect a filtration or respiration activity; and had to be high enough to prevent the bivalve from removing too much algae, and to allow us to detect accurately the time of variations in filtration and respiration activity. The out-flowing water of each chamber was successively analysed for phytoplankton (fluorescence) and oxygen concentrations. For each individual, oxygen concentration and fluorescence measurements were made at least 3 times during the $24 \mathrm{~h}$ (randomly chosen period), for $40 \mathrm{~min}$. (with a record each min.). An example of 
measurement is presented in Fig. 2. In addition and every night, a record was made from 8:00 pm to 8:00 am for one individual randomly chosen. This method was very useful to evaluate and control the activity rhythm of the animal.

During the experiment, two seawater samples (1.8 l) from the control chambers were collected. At the end of the experiment, biodeposits of each animal were also collected. Biodeposits and water samples were filtered through pre-ashed, pre-weighed Whatman GF/F filters under low vacuum. All filters were washed prior to drying. The amount of particulate organic matter (POM) and inorganic matter (PIM) was determined by drying at $60{ }^{\circ} \mathrm{C}$ for $24 \mathrm{~h}$., combusting at $450^{\circ} \mathrm{C}$ for $4 \mathrm{~h}$ and weighing on a micro-balance (+/- $0.1 \mathrm{mg})$.

\subsection{Ecophysiological data processing}

\section{Clearance and pumping rate}

Clearance rate (CR), an indicator of feeding activity, is defined as the volume of water cleared of suspended particles per unit time. In this study, CR was estimated by mean of two methods: (1) the first method used fluorescence recordings (e.g. Pouvreau et al., 1999); (2) the second method used the collected biodeposits (e.g. Iglesias et al., 1998).

In the first method ("clearance method"), CR was calculated as follows: $\boldsymbol{C R}=\frac{\boldsymbol{F R} \times(\boldsymbol{C} \mathbf{1}-\boldsymbol{C} \mathbf{2})}{\boldsymbol{C 1}}$; where CR is the clearance rate $\left(1 . h^{-1}\right), F R$ is the flow rate through the chamber $\left(1 . h^{-1}\right), \mathrm{C} 1$ is the fluorescence concentration (converted in cell. $\mathrm{l}^{-1}$ ) in the in-flowing water (determined from the reference chamber) and C2 is the fluorescence concentration (cell. $1^{-1}$ ) in the out-flowing water of the experimental chamber. Clearance rates was thus calculated for each fluorescence record (around $3 x 40=120$ records per animal), and an average was calculated for each animal.

In the second method ("bio-deposition method"), the clearance rate was indirectly estimated from bio-deposition rate, by using the inorganic content of biodeposits as an inert and quantitative tracer of filtered matter (Iglesias et al., 1998). 
Observations of individuals from the two species in our experimental system allowed us to conclude that the animals produced only faeces during the experiments. CR was then calculated as follows: $\boldsymbol{C R}=\frac{\boldsymbol{T F}}{\boldsymbol{H}} \times(\mathbf{1}-\boldsymbol{e}) / \boldsymbol{P I M}$. Where $\boldsymbol{T F}$ is the amount of faeces produced during the experiment (mg dry weight), $\boldsymbol{H}$ is the duration of the experiment (h), $\boldsymbol{e}$ is the organic content of faeces and PIM is the particulate inorganic matter in incoming seawater (i.e. the mineral part of algae, mg..$\left.^{-1}\right)$.

The real pumping rate $\left(\mathrm{PR}, 1 . \mathrm{h}^{-1}\right)$, which is equal to the volume of water processed through the palleal cavity by the animal per unit time, can be estimated on the basis of the clearance rate CR. If the particle used for the estimation of CR is retained with $100 \%$ efficiency by the bivalve's gill, CR became equal to PR. In our case, $P$. rhomboïdes exhibited well-developed eu-latero-frontal cirri (Owen, 1978), and was presumably well adapted to retain very efficiently small particles $(<2 \mu \mathrm{m})$. On the other hand, G. glycymeris belongs to a group of Microciliobranchia (Owen, 1978) and has no eu-latero-frontal cirri. The minimal size of particles for $100 \%$ retention efficiency must be consequently above 4-5 $\mu$ m (e.g. Pouvreau et al., 1999). Consequently, to make an appropriate comparison between the two species, we used in our experimentation $>4 \mu \mathrm{m}$ micro-algae and, in this study, CR is presumably a good estimation of the real PR for both species.

\section{Oxygen consumption}

The $\mathrm{O}_{2}$ consumption rate is defined as the quantity of $\mathrm{O}_{2}$ consumed by the animal per unit time (mg $\mathrm{O}_{2} \cdot \mathrm{h}^{-1}$ ). Differences in the oxygen concentration between reference and experimental chambers can be used to calculate the respiration rate $R R$, as follows: $R \boldsymbol{R}=\boldsymbol{F R} \times(\boldsymbol{O} 1-\boldsymbol{O} 2)$; where $R R$ is the respiration rate $\left(\mathrm{mgO}_{2} \cdot \mathrm{h}^{-1}\right), \mathrm{FR}$ is the flow rate through the chamber $\left(1 \cdot \mathrm{h}^{-1}\right)$, O1 is the oxygen concentration $\left(\mathrm{mgO}_{2} \cdot \mathrm{l}^{-1}\right)$ in the in-flowing water (determined from the reference chamber) and $\mathrm{O} 2$ is the oxygen concentration $\left(\mathrm{mgO}_{2} \cdot \mathrm{l}^{-1}\right)$ in the water flowing out of experimental chamber. $\mathrm{O}_{2}$ consumption was thus calculated for each oxygen concentration record (around $3 \times 40=120$ records per animal), and an average was calculated for each animal. 


\section{Filtration time activity and respiration time activity}

The Filtration Time Activity and the Respiration Time Activity, respectively FTA and RTA (\%), are defined as the total duration of filtration and respiration respectively, divided by the total recording time (e.g., Bougrier et al., 1998; Huvet 2000). These parameters were calculated for each individual on the basis of fluorescence and oxygen records : the number of records which showed a significant filtration or respiration activity was divided by the total number of records. The aim was to detect a significant difference between the two species behaviours. On the contrary of some study (Bougrier et al., 1998), RTA and FTA were not used to SFG calculations since CR and RR already represent mean values, i.e. calculated from the entire records, which contain active and inactive periods.

\section{$\underline{\text { Absorption efficiency }}$}

The Conover method (1966) was used to estimate the absorption efficiency (AE, \%). This method has been reviewed and is presented with details in Iglesias et al. (1998). As for the bio-deposition method, the assumption is that the inorganic matter contained in the food can be used as an inert tracer for the digestive processes. Thus, absorption efficiency was calculated as follows: $\boldsymbol{A} \boldsymbol{E}=\frac{\boldsymbol{f}-\boldsymbol{e}}{\boldsymbol{f} \times(\mathbf{1}-\boldsymbol{e})}$; where AE is the absorption efficiency (\%), $\mathrm{f}$ is the organic fraction of the ingested matter (= organic fraction of the suspended matter), and e is the organic fraction of the egested matter.

\section{$\underline{\text { Standardisation of size and processes }}$}

In order to compare $\mathrm{CR}$ and $\mathrm{RR}$ on the same basis for each species, it was necessary to correct for weight differences between bivalves. At the end of each experiment, ash free dry weight of soft body tissue of each individual bivalve was measured to the nearest mg, after drying at $80^{\circ} \mathrm{C}$ for 24 h. and combusting at $450^{\circ} \mathrm{C}$ for $4 \mathrm{~h}$. Physiological rate was then converted to a "standard" animal of

$1 \mathrm{~g}$ tissue weight using the following equation: $\boldsymbol{Y}_{s}=\left(\frac{W_{s}}{W_{e}}\right)^{b} \times \boldsymbol{Y}_{e}$; where $\mathrm{Y}_{\mathrm{S}}$ is the physiological rate 
for an animal of standard weight, $\mathrm{W}_{\mathrm{s}}$ the standard weight $(1 \mathrm{~g}), \mathrm{W}_{\mathrm{e}}$ the observed weight of the animal (g), $\mathrm{Y}_{\mathrm{e}}$ the uncorrected (measured) physiological rate, and $\mathrm{b}$ the weight exponent for the physiological rate function. Reviews concerning weight exponents calculated for several bivalves (see Pouvreau et al, 1999 for filtration and Table 2 in this study for respiration) show that the average weight exponents are generally around $2 / 3$ and $3 / 4$ for filtration and respiration, respectively. Moreover, these values were found to have a biological significance (e.g. West et al., 1997; Kooijman, 2000). Thus, we used it respectively for clearance rate and respiration rate.

\subsection{Scope for growth and production calculations}

The scope for growth represents the energy available to an animal for growth and reproduction, after maintenance requirements are met. The SFG was calculated using the energy balance equation, as follows: $\boldsymbol{S F G}=\boldsymbol{A R}-\boldsymbol{R} \boldsymbol{R}$; where SFG is the scope for growth $\left(\mathrm{J} \cdot \mathrm{h}^{-1}\right)$, AR is the

assimilation rate $\left(\mathrm{J} \cdot \mathrm{h}^{-1}\right)$ and $\mathrm{RR}$ is the respiration rate $\left(\mathrm{J} \cdot \mathrm{h}^{-1}\right)$. The excretion rate was neglected, and consequently the assimilation rate was assumed to be equal to the absorption rate. AR was calculated as follows: $\mathbf{A R}=(\boldsymbol{C R} \times \boldsymbol{C} \times \boldsymbol{A E}) \times \mathbf{A g}$; where CR is the clearance rate $\left(1 . \mathrm{h}^{-1}\right), \mathrm{C}$ is the algae concentration in $\mu \mathrm{g} . \mathrm{l}^{-1} \mathrm{chl} a$, and AE is the absorption efficiency. Ag is the energetic value of the algae diet in J.pg chl $a^{-1}$ and was calculated with values given in Table 1 . The measured respiration rate $\left(\mathrm{mgO}_{2} \cdot \mathrm{h}^{-1}\right)$ is converted into $\mathrm{J}^{-1}{ }^{-1}\left(1 \mathrm{mg} \mathrm{O} \mathrm{O}_{2}=0.7 \mathrm{ml} \mathrm{O}_{2}\right.$ and $\left.1 \mathrm{ml} \mathrm{O}_{2}=20.08 \mathrm{~J}\right)$.

\subsection{Statistical procedures}

All the statistical procedures were conducted with Statgraphics Plus Software. For testing the influence of a factor on a physiological rate, a Student t-test was used for pairs of data sets (if there is normality and equality of variances) and analysis of variance for 3 or more data sets when it was possible (normal distributions and equality of variances). Otherwise a Kruskal-Wallis $\mathrm{H}$ test of the 
equality of medians was performed. When the analysis of variance showed a significant difference between the different data sets, a simple regression allowed us to test the trend.

For testing differences between the two species, a Student t-test of the equality of means was performed when it was possible (normal distribution and equality of variances), otherwise a MannWhitney W-test of the equality of medians. 


\section{Results}

A total of 44 P. rhomboïdes and 44 G. glycymeris were used for the experiments. Their weights range from 0.27 to $0.81 \mathrm{~g}$ AFDW for P. rhomboïdes (average: 0.45 g AFDW, SD: 0.12), and from 0.36 to $1.30 \mathrm{~g}$ AFDW for G. glycymeris (average: $0.89 \mathrm{~g}$ AFDW, SD: 0.23). However, all measurements were not used, because of technical problems (variations of temperature or of phytoplankton providing, displacement of animals in the experimental chambers...).

\subsection{Preliminary comparison of the CR-methods}

Clearance rate was estimated by mean of two complementary methods: the "clearance" and the "biodeposition" methods; this part presents the comparison that can be established between the two methods. For both species, Fig. 2 shows a positive relationship between the two methods. This relationship was significant for G. glycymeris but not for P. rhomboïdes. Nevertheless, results demonstrated that clearance rates calculated by the bio-deposition method were generally higher than those calculated by the continuous recording method (difference of approx. $30 \%$ ).

\subsection{Effect of temperature and food concentration}

\section{Effect on time activity}

In the range of tested values, temperature and phytoplankton concentration showed no effect on either the respiration time activity or the filtration time activity for both species (Kruskal-Wallis $\mathrm{H}$ test, Table 3.1).

\section{$\underline{\text { Effect on CR and RR mean values }}$}

Standardised mean CR-values and RR-values are plotted as a function of temperature (Fig. 3 and 4). The graphs indicate a positive influence of temperature on CR and RR values, but the ANOVA and Kruskall-Wallis test (Table 4.2) did not confirm that it is significant (variance in the samples was relatively high), except for $P$. rhomboïdes, where ANOVA revealed some significant differences in $\mathrm{CR}$ but without any typical trend. In the narrow range of water temperature $\left(12-18^{\circ} \mathrm{C}\right)$, temperature effect on CR and RR appears to be a non-significant parameter for both species. 
Standardised individual means of CR are plotted as a function of chlorophyll concentration (Fig. 5). In this range of values, food concentration has not a significant influence on CR of Glycymeris glycymeris (Table 3.2). On the other hand, ANOVA results suggest a significant relation exist between CR of Paphia rhomboïdes and chlorophyll concentration $\left(Y=e^{\mathbf{0 . 7 8}-\frac{\mathbf{1 . 6}}{\boldsymbol{X}}} ; \mathrm{n}=33, \mathrm{R}^{2}=40 \%\right)$.

\subsection{Mean physiological values and comparison between the two species}

Since temperature and phytoplankton concentration exhibited no or little effects on the filtration and respiration, in the range of tested values, we pooled all the data to properly compare the two species. Mean values of physiological data are given in Table 4.

It appeared that the physiology of $P$. rhomboïdes and G. glycymeris are strictly different. As a general case, $P$. rhomboïdes shows higher filtration time activity, clearance rate and respiration values than G. glycymeris. Only respiration time activity was equal between the two species. Clearance values are 4-fold higher in P. rhomboïdes, independent of the method, and absorption was also more efficient (89 \% for P. rhomboïdes against 78\% for G. glycymeris). The oxygen consumption was about 2-fold higher for P. rhomboïdes.

Finally, during the collection of biodeposits in the individual chambers, an important difference was noted between the faeces of the two species. Dog cockle's faeces were dense and compacted in small pieces while banded carpet shell’s faeces were not dense and were stringy.

\subsection{Scope for growth}

On the basis of all the mean ecophysiological values obtained above and considering that physiology was not influenced by temperature or food concentration in the tested range, the scope for growth was calculated for a standard animal of $0.5 \mathrm{~g}$ flesh DW, for both species. Fig. 6 shows individual SFG values as a function of phytoplankton concentrations. It appears that $P$. rhomboïdes exhibits higher SFG values than G. glycymeris, except for low concentration, and consequently a higher growth and presumably a higher reproduction output. 


\section{Discussion}

\subsection{Reliability of the methods and the results}

In our study, two methods were used in order to estimate clearance rates for both species: the "biodeposition" method (e.g. Iglesias et al., 1998) and the "clearance" method (e.g. Coughlan, 1969). Each method exhibits advantages and disadvantages.

Concerning "biodeposition method", the collecting step was the main source of variability. For example, faeces of $P$. rhomboïdes, which were very little, dense and compacted were less easy to collect than those of G. glycymeris and may consequently be underestimated. Moreover, the collecting took place at the end of the experiments, which lasted from $24 \mathrm{~h}$ to $46 \mathrm{~h}$. In such conditions, the development of a bacterian activity on the faeces could occur and may have contributed to the greater variability in the results of biodeposition method (P. rhomboïdes).

Concerning "clearance method", the duration of the measure may sometimes be too short. For example, the first results obtained on G. glycymeris for filtration rates and filtration time activity showed a great temporal variability, so we suspected our sampling method of filtration records (2 or 3 periods of $40 \mathrm{~min}$ ) to be, in some case, unsuited and less representative. On the other hand, the biodeposition method allows one to integrate results for a complete day. And consequently, when bivalve's activity varies significantly, this method becomes more reliable.

For $P$. rhomboïdes, we were more confident about the results of continuous recording method since the clearance rate appeared to be fairly constant over times. Furthermore, the filtration activity of individuals was easier to control because of the occurrence of siphons, which constitutes a good indicator of the feeding activity.

Thus, for $P$. rhomboïdes the continuous recording method appears to be more suitable, while both methods gave satisfying and relevant results for G. glycymeris, even if the biodeposition method gave higher CR-values. 
It has been stated that the respiration activity may constitute a relevant indicator for evaluating the stress of bivalves (e.g. Akberali and Trueman, 1985; Huvet, 2000). We found that the respiration time activities of both species were very close to $100 \%$, which suggests that the animals were not under stress during the experiments, and confirms the validity of the results.

It is often admitted that physiological perturbations may occur during gametogenesis and spawning period (Soletchnik et al., 1997; Bougrier et al., 1998). In our case, 58\% of the G. glycymeris individuals used for experiments were mature, and may consequently demonstrate a more variable activity. However, averages of clearance and respiration rates between mature and immature individuals were not significantly different.

\subsection{Comparison with the values of literature}

The lack of knowledge on G. glycymeris and $P$. rhomboïdes is very impressive and data on ecophysiology for both species are quite scarce.

Concerning G. glycymeris, Brand and Morris (1984) found that their pumping rate was very low for a filter-feeding bivalve, around $0.06 \mathrm{l} \cdot \mathrm{h}^{-1} \cdot \mathrm{g}^{-1}$. According to them, the pumping rate was limited by morphological constraints: the labial palps are poorly developed (unlike most bivalves), and particle sorting must take place on ctenidia only. Important differences exist between their results and ours, since we found an average filtration rate 10 times higher $\left(0.4\right.$ or $0.71 . h^{-1}$ depending on the method used). This considerable difference would presumably find an explanation in the fact that $G$. glycymeris exhibits a high variability in feeding activity. Brand and Morris (1984) found that the 'time spent pumping' was about $60 \%$, which is very close to our calculated Feeding Time Activity. This suggests that G. glycymeris could have a periodic feeding activity, with active periods (high filtration) alternating with "inactive” periods (no or low filtration, but digestion and defecation). The fact that faeces of G. glycymeris were separated, very compacted and dense tends to confirm this periodic activity. Concerning respiration rate, the differences between the two studies were less: $1.1 \mathrm{mgO}_{2} \cdot \mathrm{h}^{-1} \cdot \mathrm{g}^{-1}$ for Brand and Morris (1984) and $0.3 \mathrm{mgO}_{2} \cdot \mathrm{h}^{-1} \cdot \mathrm{g}^{-1}$ in our study. 
Concerning $P$. rhomboïdes, no published information could be found on its ecophysiology, and our results bring the first data on clearance and respiration rates for this species. Nevertheless, an abundant bibliography exists about closely related species, especially for Ruditapes philippinarum and Tapes decussatus, which are cultivated and/or introduced species.

Our results demonstrated that $P$. rhomboïdes exhibits a fairly constant filtration activity around $90.8 \%$. Owing to a method based on temperature measurements in seawater, sediment and shellfish, Defossez (1995) also found that pumping activity in Ruditapes philippinarum was nearly continuous (excepted during the low tide). Nevertheless, our results demonstrate that the filtration rate was fairly constant during the experiments whereas Defossez (1995) showed that filtration rate continuously changes in natural conditions. Mean standardised CR-values in our study were around $1.7 \mathrm{l}^{-1} \mathrm{~h}^{-1} \mathrm{~g}^{-1}$ for $\mathrm{P}$. rhomboïdes, which is very close to standardised CR-values given in the literature for Ruditapes philippinarum: 0.5-1.5 $1 . \mathrm{h}^{-1} \cdot \mathrm{g}^{-1}$ (Goulletquer et al., 1989), $2.2 \mathrm{l} \cdot \mathrm{h}^{-1} \cdot \mathrm{g}^{-1}$ (Defossez and Daguzan, 1995), $2.3 \mathrm{l} \cdot \mathrm{h}^{-1} \cdot \mathrm{g}^{-1}$ (average, Nakamura, 2001) and for Tapes decussatus: $2.7 \mathrm{l} \cdot \mathrm{h}^{-1} \cdot \mathrm{g}^{-1}$ (Defossez and Daguzan, 1995), 2.1-3.8 $1 . \mathrm{h}^{-1} \cdot \mathrm{g}^{-1}$ (Riva and Massé, 1983).

Concerning oxygen consumption, the mean value obtained in the present study was around $0.55 \mathrm{mgO}_{2} \cdot \mathrm{h}^{-1} \cdot \mathrm{g}^{-1}$, which is in the range of values obtained for both these species. For example, the range of standardised values obtained for Ruditapes philippinarum was between $0.9-1.1 \mathrm{mgO}_{2} \cdot \mathrm{h}^{-1} \cdot \mathrm{g}^{-}$ ${ }^{1}$ (Bodoy et al., 1986) and 0.15-0.5 $\mathrm{mgO}_{2} \cdot \mathrm{h}^{-1} \cdot \mathrm{g}^{-1}$ (Goulletquer et al., 1989). For Tapes decussatus, mean values were also in the same range: 0.4-0.5 $\mathrm{mgO}_{2} \cdot \mathrm{h}^{-1} \cdot \mathrm{g}^{-1}$ (Bodoy et al., 1986), 0.7-1.4 $\mathrm{mgO}_{2} \cdot \mathrm{h}^{-}$ ${ }^{1} \cdot \mathrm{g}^{-1}$ (Riva and Massé, 1983).

\subsection{Influence of environmental conditions}

Ecophysiological functions, especially clearance and respiration rates, depend directly on environmental conditions (food concentration, temperature...). In our study, a significant correlation between chlorophyll a concentration and clearance rate was found for Paphia rhomboïdes. Individuals exhibit particularly low filtration rates at the lowest chlorophyll 
concentration (1 $\mu$ g chlo $\left.a . \mathrm{l}^{-1}\right)$, visually confirmed by a reduced opening state compared to its usual behaviour. To confirm this result, at the end of one of the concerned experiments, the algal concentration was progressively increased to $5 \mu \mathrm{g}$ chlo $a . \mathrm{l}^{-1}$ and the animal behaviour was observed during a couple of hours. Within half an hour after the shift in food concentration, the filtration rate increased, and the siphons came out and opened well.

The filtration rate is well known to increase asymptotically with algal concentration in order to optimise the energetic expenditure due to the filtration activity. Thus, working on Cardium edule, Mytilus edulis and Mya arenaria, Riisgard et al. (2003) found that bivalves show reduced valve and siphon opening in low algal concentrations and estimated a threshold values of $0.5 \mu \mathrm{g}$ chlo a. $\mathrm{l}^{-1}$ below which bivalves stop active filtration. Above this threshold, it is commonly supposed (e.g. Winter, 1979) that the filtration rate increases in order to ensure a maximum ingestion rate. As soon as this maximum ingestion rate is reached, the filtration rate decrease continuously in such a way that the amount of food ingested is kept constant (Bayne et al., 1989; Fiala-Medioni et al., 1983). Our work confirms the first part of this asymptotic relation between the filtration rate and the phytoplankton concentration. It would be interesting to test higher values of chlorophyll $a$ concentration to confirm the complete behaviour.

The temperature is also a key-factor, well known to play a significant role on physiology of ectotherm species. In the present study, the aim was to test the influence of temperature in its natural range of variation. In the 'Golfe Normand-Breton', Paphia rhomboïdes and Glycymeris glycymeris live in a subtidal habitat where the temperature ranges from $8^{\circ} \mathrm{C}$ to $18^{\circ} \mathrm{C}$ (Hoch, 1998). Due to technical problems, we were not able to test the coldest temperatures, but will be planned to tested soon. In the investigated range of temperature, there was no evidence that temperature significantly influences either pumping or respiration rate for both species. A larger range of temperature would probably show at least a slight influence on CR and RR, however our result 
comply with the fact that Paphia rhomboïdes and Glycymeris glycymeris are two eurytherm species, characterised by a wide distribution with little climatic requirements (Holmes, 1966; Gentil, 1976). Previous work had lead to the same conclusion. Working on $R$. philippinarum, Goulletquer et al. (1989) found that filtration of $R$. philippinarum was nearly constant between 12 and $20^{\circ} \mathrm{C}$. Similarly, working on R. philippinarum and T. decussatus, Defossez and Daguzan (1995) showed no significant changes in pumping rates from 19 to $29^{\circ} \mathrm{C}$. It was also demonstrated that production of Mytilus edulis was virtually independent of temperature between 5 and $20^{\circ} \mathrm{C}$ (Widdows, 1978).

\subsection{Bio-energetic inter-specific comparisons and ecological implications}

Our results clearly show that under the same experimental conditions P. rhomboïdes and G. glycymeris have different feeding behaviours. P. rhomboïdes exhibited a higher and continuous feeding activity with a continuous filtration and presumably continuous faeces production. Hily (1983) also found that Ruditapes philippinarum has a continuous digestion. On the contrary, G. glycymeris showed a lower and periodic feeding activity, with a filtration time activity around 60\% and probably a longer digestion (faeces of higher density and compacted in small pieces). The consequence is that the SFG was significantly higher for $P$. rhomboïdes under these experimental conditions. This result helps to explain the differences observed in growth potentialities between two species inhabiting the same sediment.

Nevertheless, this result needs to be moderated since in natural habitat G. glycymeris could feed on another kind of food than $P$. rhomboïdes. Several elements strengthen this assumption. For example, it has been said that 'In gravel, G. glycymeris burrows below the surface to a depth of at least several centimetres and can still obtain sufficient water currents for respiratory and feeding purposes through the substrate' (Ansell and Trueman, 1967). Consequently, G. glycymeris could potentially feed on particles in the interstitial seawater. P. rhomboïdes and G. glycymeris lives in coarse sediment in areas with relatively high bottom currents. But G. glycymeris do not have 
siphons, and could complete its weak active nutrition by a passive nutrition due to the movements of seawater that could go through its pallial cavity.

The next stage will be to test these different hypotheses and the ability of G. glycymeris and $P$. rhomboïdes to growth in real conditions with the help of a trophic model. This trophic model will constitute a useful tool for ecology and fisheries management.

\section{Acknowledgements}

This work was supported by IFREMER and Région Bretagne funding. Thanks to the staff of Argenton IFREMER station (DRV/RA) for technical support and algae providing, to Mr Brezellec, owner of the Shamrock, and to Alain Ménesguen (IFREMER/DEL/EC) to his critical reading of the manuscript. Informations about bivalves fisheries come from an IFREMER database (SIH, Système d'informations halieutiques, Patrick Berthou). The experiments done on P. rhomboïdes and G. glycymeris comply with the currents laws of France. 


\section{References}

Akberali, H.B., Trueman, E.R., 1985. Effects of environmental stress on marine bivalve molluscs. Adv. Mar. Biol. 22, 101-136.

Ansell, A.D., Trueman, E.R., 1967. Observations on burrowing in Glycymeris glycymeris (L.) (Bivalvia, Arcacea). J. Exp. Mar. Biol. Ecol. 1, 65-75.

Bayne, B.L., Hawkins, A.J.S., Navarro, E., Iglesias, I.P., 1989. Effects of seston concentration on feeding, digestion and growth in the mussel Mytilus edulis. Mar. Ecol. Prog. Ser. 55, 47-54.

Bernard, F.R., 1983. Physiology and the mariculture of some north-eastern Pacific bivalve molluscs. Can. Spec. Publ. Fish. Aquat. Sci. 63, 1-24.

Bodoy, A., Riva, A., Maitre-Allain, T., 1986. A comparison of oxygen consumption in the carpetshell clam, Ruditapes decussatus (L.) and the manila clam $R$. philippinarum as a function of temperature. Vie et milieu 36, 83-89.

Bougrier, S., Geairon, P., Deslous-Paoli, J.M., Bacher, C., Jonquières, G., 1995. Allometric relationships and effects of temperature on clearance and oxygen consumption rates of Crassostrea gigas (Thunberg). Aquaculture 134, 143-154.

Bougrier, S., Collet, B., Geairon, P., Geffard, O., Héral, M., Deslous-Paoli, J.M., 1998. Respiratory time activity of the Japanese oyster Crassostrea gigas (Thunberg). J. Exp. Mar. Biol. Ecol. 219, 205-216.

Brand, A.R., Morris, D.J., 1984. The respiratory responses of the dog cockle Glycymeris glycymeris (L.) to declining environmental oxygen tension. J. Exp. Mar. Biol. Ecol. 83, 89-106.

Brown, M.R., 1991. The amino-acid and sugar composition of 16 species of microalgae used in mariculture. J. Exp. Mar. Biol. Ecol. 145, 79-99.

Brown, M.R., Jeffrey, S.W., 1992. Biochemical composition of microalgae from the green algal classes Chlorophycae and Prasinophyceae. 1. Amino acids, sugars and pigments. J. Exp. Mar. Biol. Ecol. 161, 91-113. 
Brown, M.R., Jeffrey, S.W., Volkman, J.K., Dunstan, G.A., 1997. Nutritional properties of microalgae for mariculture. Aquaculture 151, 315-331.

Cabioch, L., 1968. Contribution à la connaissance des peuplements benthiques de la Manche Occidentale. Cah. Biol. Mar. IX 5., 720pp.

Coughlan, J., 1969. The estimation of filtering rate from the clearance of suspensions. Mar. Biol. 2, 356-358.

Defossez, J.M., 1995. Activité de pompage in situ de Ruditapes philippinarum (Bivalvia, veneridae). J. Rech. Oceanogr. 20, 149.

Defossez, J.M., Daguzan, J., 1995. Mesure comparative du débit palléal des bivalves Tapes decussatus et Ruditapes philippinarum lors de changements de température et de turbidité. Cah. Biol. Mar. 36, 299-307.

Fiala-Medioni, A., Copello, M., Colomines, J.C., 1983. Relations trophiques entre huîtres et milieu; influence de la concentration et de la taille des particules. Bases biologiques de l'aquaculture, Montpellier, 1983. IFREMER Actes de colloques 1, 63-74.

Gentil, F., 1976. Distribution des peuplements benthiques en baie de Seine. Thèse de l'université de Paris VI, 470pp.

Goulletquer, P., Heral, M., Deslous-Paoli, J.M., Prou, J., Garnier, J., Razet, D., Boromthanarat, W., 1989. Ecophysiologie et bilan énergétique de la palourde japonaise d'élevage Ruditapes philippinarum. J. Exp. Mar. Biol. Ecol. 132, 85-10.

Haure, J., Penisson, C., Bougrier, S., Baud, J.P., 1998. Influence of temperature on clearance and oxygen consumption rates of the flat oyster Ostrea edulis : determination of allometric coefficients. Aquaculture 169, 211-224.

Hily, A.,1983. Etude histoenzymologique de la digestion chez Ruditapes philippinarum. Bases biologiques de l'aquaculture, Montpellier, 1983. IFREMER Actes de colloques 1, 97-108. 
Hoch, T., 1998. Modélisation du réseau trophique pélagique et de la production primaire en Manche. Ocean. Acta 21, 871-885.

Holmes, N.A., 1966. The bottom fauna of the English Channel. Part II. J. Mar. Biol. Assoc. U. K. $46,401-493$.

Huvet, A., 2000. Ressources génétiques et phylogéographie des huîtres creuses Crassostrea gigas et C. angulata : variabilité, différenciation et adaptation des populations naturelles et introduites. Thèse de doctorat, Univ. Tours (France), 153-169.

Iglesias, J.I.P., Urrutia, M.B., Navarro, E., Ibarrola, I., 1998. Measuring feeding and absorption in suspension-feeding bivalves : an appraisal of the biodeposition method. J. Exp. Mar. Biol. Ecol., 219, 71-86.

Kooijman, S.A.L.M., 2000. Dynamic Energy and Mass Budgets in Biological Systems, $2^{\text {nd }}$ Edition. Cambridge University Press, 424 pp.

Morvan, C., 1987. Cycle de reproduction et fécondité de deux espèces de bivalves dans le golfe Normand-Breton. Thèse de doctorat, Univ. Bretagne Occidentale (Brest, France), 138 pp.

Nakamura, Y., 2001. Filtration rates of the Manila clam, Ruditapes philippinarum : dependence on prey items including bacteria and picocyanobacteria. J. Exp. Mar. Biol. Ecol. 266, 181-192.

Newell, R.I.E., 1977. The ecophysiology of Cardium edule (L.). Ph.D Thesis, University of London, London, England.

Noël, P., Blanchard, M., Berthou, P., 1995. Cartographie et évaluation des principaux mollusques filtreurs du golfe Normand-Breton. Rapport interne DEL-DRV/RH /95.11, 31 pp.

Owen, G., 1978. Classification and the bivalve gill. Phil Trans. R. Soc. Lond. B 284, 377-385.

Pouvreau, S., Jonquières, G., Buestel, D., 1999. Filtration by the pearl oyster, Pinctada margaritifera, under conditions of low seston load and small particle size in a tropical lagoon. Aquaculture 176, 295-314. 
Ramsay, K., Kaiser, M.J., Richardson, C.A., Veale, L.O., Brand, A.R., 2000. Can shell scars on dog cockles (Glycymeris glycymeris L.) be used as an indicator of fishing disturbance? J. Sea Res. 43, 167-176.

Rétiere, C., 1979. Contribution à la connaissance des peuplements benthiques du golfe Normannobreton. Thèse de doctorat, Univ. Rennes (France). 421 pp.

Riisgard, H.U., Kittner, C., Seerup, D.F., 2003. Regulation of opening state and filtration rate in filter-feeding bivalves (Cardium edule, Mytilus edulis, Mya arenaria) in response to low algal concentration. J. Exp. Mar. Biol. Ecol. 284, 105-127.

Riva, A., Massé, H., 1983. Etude écophysiologique de quelques mollusques bivalves. In, Bases biologiques de l’aquaculture, edited by IFREMER, Act. Coll., Vol. 1, 45-62.

Soletchnik, P., Razet, D., Geairon, P., Faury, N., Goulletquer, P., 1997. Ecophysiologie de la maturation sexuelle et de la ponte de l’huître creuse Crassostrea gigas : réponses métaboliques (respiration) et alimentaires (filtration, absorption) en fonction des différents stades de maturation. Aquat. Living Resour. 10, 177-185.

Steingrimsson, S.A., 1989. A comparative ecological study of two Glycymeris glycymeris (L.) populations of the Isle of Mann. PhD, University of Liverpool, $121 \mathrm{pp}$.

West, G.B., Brown, J.H., Enquist, B.J., 1997. A general model for the origin of allometric scaling laws in biology. Science 276, 122-126.

Widdows, J., 1978. Physiological indices of stress in Mytilus edulis. J. Mar. Biol. Assoc. U.K. 58, $125-142$.

Winter, J.E., 1979. A critical review on some aspects of filter-feeding in lamellibranchiate bivalves. Haliotis 7, 71-87.

Whyte, J.N.C., 1987. Biochemical composition and energy content of six species of phytoplankton used in mariculture of bivalves. Aquaculture 60, 231-241. 


\section{TABLES}

$\underline{\text { Table } 1}$ : Characteristics of algae used to feed the bivalves.

$\underline{\text { Table } 2}$ : Literature review of allometric coefficients (b) obtained for respiration rates.

Table 3: Results of statistic tests performed to test the influence of temperature and food concentration on the ecophysiology of both species. The test statistic is F for an ANOVA, and H for a Kruskall-Wallis test. In both case the null hypothesis is: the tested parameter has no influence. (The result of the test made on the influence of the temperature on RTA of P. rhomboids is an artefact due to the occurrence of one RTA lower than $100 \%$ at $12^{\circ} \mathrm{C}$, while all the others were equal to $100 \%$.)

Table 4 : Comparison of the values of different physiological parameters in both species. A statistical test was made to compare these values: a Student t-test on the equality of means when the samples come from a normal distribution and there is equality of variances, and otherwise a MannWhitney W-test on the equality of median. In both case, the null hypothesis is mean or median $1=$ mean or median 2 . 
Table 1: Characteristics of algae used to feed the bivalves.

\begin{tabular}{|c|c|c|c|c|c|}
\hline Algal class species & Size $\mu \mathrm{m}$ (ESD) & Chl a pg/cell & Energetic values J/mg DW & Dry weight pg/cell & $\%$ of total weight in the mixture \\
\hline \multicolumn{6}{|l|}{ Bacillariophycae } \\
\hline Chaetoceros calcitrans & 5.6 & 0.34 & 12.3 & 43 & 33 or 0 \\
\hline Skeletonema costatum & 5.7 & 0.63 & & 45 & 0 or 33 \\
\hline \multicolumn{6}{|l|}{ Prasinophycae } \\
\hline Tetraselmis chui & 8.6 & 3.83 & 10.7 (T. suecica) & 220 & 33 \\
\hline Prymnesiophycae & & & & & \\
\hline Isochrisis aff. galbana (T-iso) & 4.3 & 0.29 & 17.7 & 19 & 33 \\
\hline
\end{tabular}

References : Brown, 1991; Brown et al, 1997; Whyte, 1987; Brown and Jeffrey, 1992; R. Robert, unpublished data. 


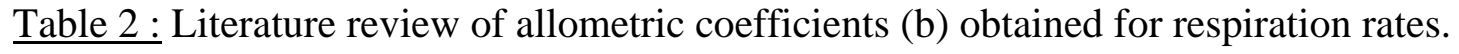

\begin{tabular}{|l|c|l|}
\hline Species & Allometric coefficients & Authors \\
\hline Cerastoderma edule & 0.53 & Newell, 1977 \\
Crassostrea gigas & 0.8 & Bougrier et al., 1995 \\
Mytilus edulis & 0.66 & Rotthauwe, 1958 (in Riva and Massé, 1983) \\
Mytilus edulis & 0.595 & Read, 1962 (in Riva and Massé, 1983) \\
Mytilus edulis & 0.724 & Bayne et al., 1973 (in Riva and Massé, 1983) \\
Mytilus edulis & 0.67 & Bayne et al., 1973 (in Riva and Massé, 1983) \\
Mytilus galloprovincialis & 0.407 & Riva and Massé, 1983 \\
Ostrea edulis & 0.8 & Haure et al., 1998 \\
Ruditapes aureus & 1.204 & Riva and Massé, 1983 \\
Ruditapes aureus & 0.623 & Riva and Massé, 1983 \\
Ruditapes aureus & 0.74 & Riva and Massé, 1983 \\
Ruditapes aureus & 0.819 & Riva and Massé, 1983 \\
Ruditapes aureus & 0.805 & Riva and Massé, 1983 \\
Ruditapes decussatus & 0.593 & Riva and Massé, 1983 \\
Ruditapes philippinarum & 0.507 & Goulletquer et al., 1989 \\
Ruditapes philippinarum & 0.807 & Bernard, 1983 \\
Ruditapes philippinarum & 1.058 & Bodoy et al., 1986 \\
Tapes decussatus & 0.593 & Riva and Massé, 1983 \\
Tapes decussatus & 0.87 & Bodoy et al., 1986 \\
\hline Global mean & $\mathbf{0 . 7 3}$ & \\
\cline { 1 - 3 } & \multicolumn{2}{|l}{}
\end{tabular}


Table 3 : Results of statistic tests performed to test the influence of temperature and food concentration on the ecophysiology of both species. The test statistic is F for an ANOVA, and H for a Kruskall-Wallis test. In both case the null hypothesis is: the tested parameter has no influence. (The result of the test made on the influence of the temperature on RTA of $P$. rhomboïdes is an artefact due to the occurrence of one RTA lower than $100 \%$ at $12^{\circ} \mathrm{C}$, while all the others were equal to $100 \%$.).

\begin{tabular}{|l|c|c|c|c|}
\cline { 2 - 5 } \multicolumn{1}{c|}{} & \multicolumn{2}{c|}{ P. rhomboïdes } & \multicolumn{2}{c|}{ G. glycymeris } \\
\cline { 2 - 5 } \multicolumn{1}{c|}{} & $\mathrm{FTA}$ & $\mathrm{RTA}$ & $\mathrm{H}=2.55$ & $\mathrm{H}=1.17$ \\
& $\mathrm{H}=0.66$ & $\mathrm{H}=9$ & $p=0.28$ & $p=0.56$ \\
& $p=0.72$ & $p=0.01$ & $\mathrm{n}=30$ & $\mathrm{n}=13$ \\
\hline Temperature effect & $\mathrm{n}=34$ & $\mathrm{H}=20$ & $\mathrm{H}=1.17$ & $\mathrm{H}=1.60$ \\
& $\mathrm{H}=3.1$ & $p=0.76$ & $p=0.56$ & $p=0.66$ \\
& $p=0.54$ & $\mathrm{n}=20$ & $\mathrm{n}=30$ & $\mathrm{n}=13$ \\
\hline
\end{tabular}

3.1 : Filtration and Respiration Time Activities

\begin{tabular}{|l|c|c|c|c|}
\cline { 2 - 5 } \multicolumn{1}{c|}{} & \multicolumn{2}{c|}{ P. rhomboïdes } & \multicolumn{2}{c|}{ G. glycymeris } \\
\cline { 2 - 5 } \multicolumn{1}{c|}{} & $\mathrm{CR}$ & $\mathrm{RR}$ & $\mathrm{CR}$ & $\mathrm{HR}$ \\
\hline Temperature effect & $\mathrm{F}=7.53$ & $p=0.99$ & $\mathrm{H}=0.19$ \\
& $p=0.00$ & $\mathrm{n}=36$ & $p=0.61$ & $p=0.91$ \\
& 33 & $\mathrm{~F}=1.36$ & $\mathrm{n}=28$ & $\mathrm{n}=27$ \\
\hline Food effect & $\mathrm{F}=4.63$ & $p=0.27$ & $p=0.82$ & $p=0.36$ \\
& $p=0.01$ & $\mathrm{n}=35$ & $\mathrm{n}=28$ & $\mathrm{n}=25$ \\
\hline
\end{tabular}

3.2 : Clearance and Respiration Rates 
Table 4 : Comparison of the values of different physiological parameters in both species. A statistical test was made to compare these values: a Student t-test on the equality of means when the samples come from a normal distribution and there is equality of variances, and otherwise a MannWhitney $\mathrm{W}$-test on the equality of median. In both case, the null hypothesis is mean or median $1=$ mean or median 2.

\begin{tabular}{|c|c|c|c|c|c|}
\hline & & Paphia rhomboïdes & Glycymeris glycymeris & Statistic test & P-value \\
\hline FTA (\%) & $\begin{array}{c}\text { average } \\
\min -\max \\
\mathrm{n}\end{array}$ & $\begin{array}{c}\mathbf{9 0 . 3} \\
28.6-100 \\
34\end{array}$ & $\begin{array}{c}\mathbf{6 1 . 5} \\
0-100 \\
30\end{array}$ & $W=735$ & 0.0008 \\
\hline RTA (\%) & $\begin{array}{c}\text { average } \\
\min -\max \\
n\end{array}$ & $\begin{array}{c}\mathbf{9 9 . 2} \\
84.4-100 \\
20\end{array}$ & $\begin{array}{c}99.9 \\
99.3 \\
13\end{array}$ & $W=133$ & 0.8238 \\
\hline 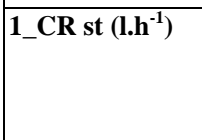 & $\begin{array}{c}\text { average } \\
\min -\max \\
\mathrm{n}\end{array}$ & $\begin{array}{c}\mathbf{1 . 6 7 4 9} \\
0.1104-3.0334 \\
33\end{array}$ & $\begin{array}{c}\mathbf{0 . 4 2 1 6} \\
0-1.8521 \\
28\end{array}$ & $W=836$ & 0.0000 \\
\hline 2_CR st $\left(1 . h^{-1}\right)$ & $\begin{array}{c}\text { average } \\
\min -\max \\
n\end{array}$ & $\begin{array}{c}\mathbf{3 . 6 9 5 7} \\
1.2386-6.7829 \\
13\end{array}$ & $\begin{array}{c}\mathbf{0 . 6 5 5 5} \\
0.0328-2.0262 \\
12\end{array}$ & $\mathrm{~W}=2$ & 0.0000 \\
\hline AE (\%) & $\begin{array}{c}\text { average } \\
\text { conf. interval } \\
n\end{array}$ & $\begin{array}{c}\mathbf{8 9 . 7 1} \\
86.98-92.45 \\
14\end{array}$ & $\begin{array}{c}\mathbf{7 8 . 2 7} \\
72.42-84.12 \\
11\end{array}$ & $\mathrm{t}=4.2$ & 0.0003 \\
\hline RR (mg O2.h ${ }^{-1}$ ) & $\begin{array}{c}\text { average } \\
\text { conf. interval } \\
\mathrm{n}\end{array}$ & $\begin{array}{c}\mathbf{0 . 5 5 4 7} \\
0.4615-0.6480 \\
20\end{array}$ & $\begin{array}{c}\mathbf{0 . 3 0 3 4} \\
0.2115-0.3954 \\
13\end{array}$ & $t=3.87$ & 0.0005 \\
\hline
\end{tabular}




\section{FIGURES}

Figure 1: The ecophysiological experimental system. A: general view, B: individual chamber (C : chamber, FG : floodgate, $\mathrm{O} 2$ : oxymeter, $\mathrm{T}$ : thermometer, $\mathrm{CH}$ : fluorimeter)

Figure 2: Examples of CR and RR measurements (continuous recording method) for P. rhomboïdes

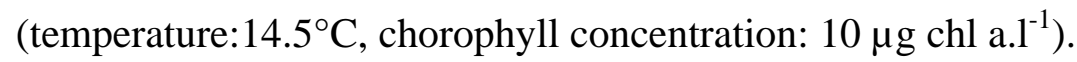

Figure 3: Mean individual clearance rates obtained by the biodeposition method (2) plotted against the corresponding clearance rates obtained by continuous recording method (1). For G. glycymeris, there was a significant relation $\mathbf{Y}=\mathbf{0 . 2 7}+\mathbf{1 . 0 4} \times \boldsymbol{X} \quad\left(\mathrm{n}=12, \mathrm{R}^{2}=0.731\right.$, slope $\mathrm{P}=0.0004$, intercept $\mathrm{p}=0.0362$ ). For $P$. rhomboïdes, the relation was not significant.

$\underline{\text { Figure } 4}$ : Clearance Rate of both species as a function of temperature (mean $\pm \mathrm{SE}$ ).

Figure 5: Respiration Rate of both species as a function of temperature (mean $\pm \mathrm{SE}$ ).

Figure 6: Clearance Rate of both species as a function of chlorophyll concentration (mean \pm SE).

Model P. rhomboïdes : $Y=e^{0.78-\frac{1.6}{X}} \quad\left(n=33, \mathrm{R}^{2}=40 \%\right.$, slope $\mathrm{P}=0.0001$, intercept $\left.\mathrm{P}=0.0000\right)$.

Figure 7: Scope For Growth as a function of phytoplankton concentration (individual means \pm SE).

Model P. rhomboïdes : $Y=1.8 \times X-8.2$ (n=30, $\mathrm{R}^{2}=62 \%$, slope $\mathrm{P}=0.0000$, intercept $\left.\mathrm{P}=0.0004\right)$.

Model G. glycymeris : $Y=0.7 \times X-5.1$ ( $\mathrm{n}=22, \mathrm{R}^{2}=32 \%$, slope $\mathrm{P}=0.0053$, intercept $\left.\mathrm{P}=0.0170\right)$. 


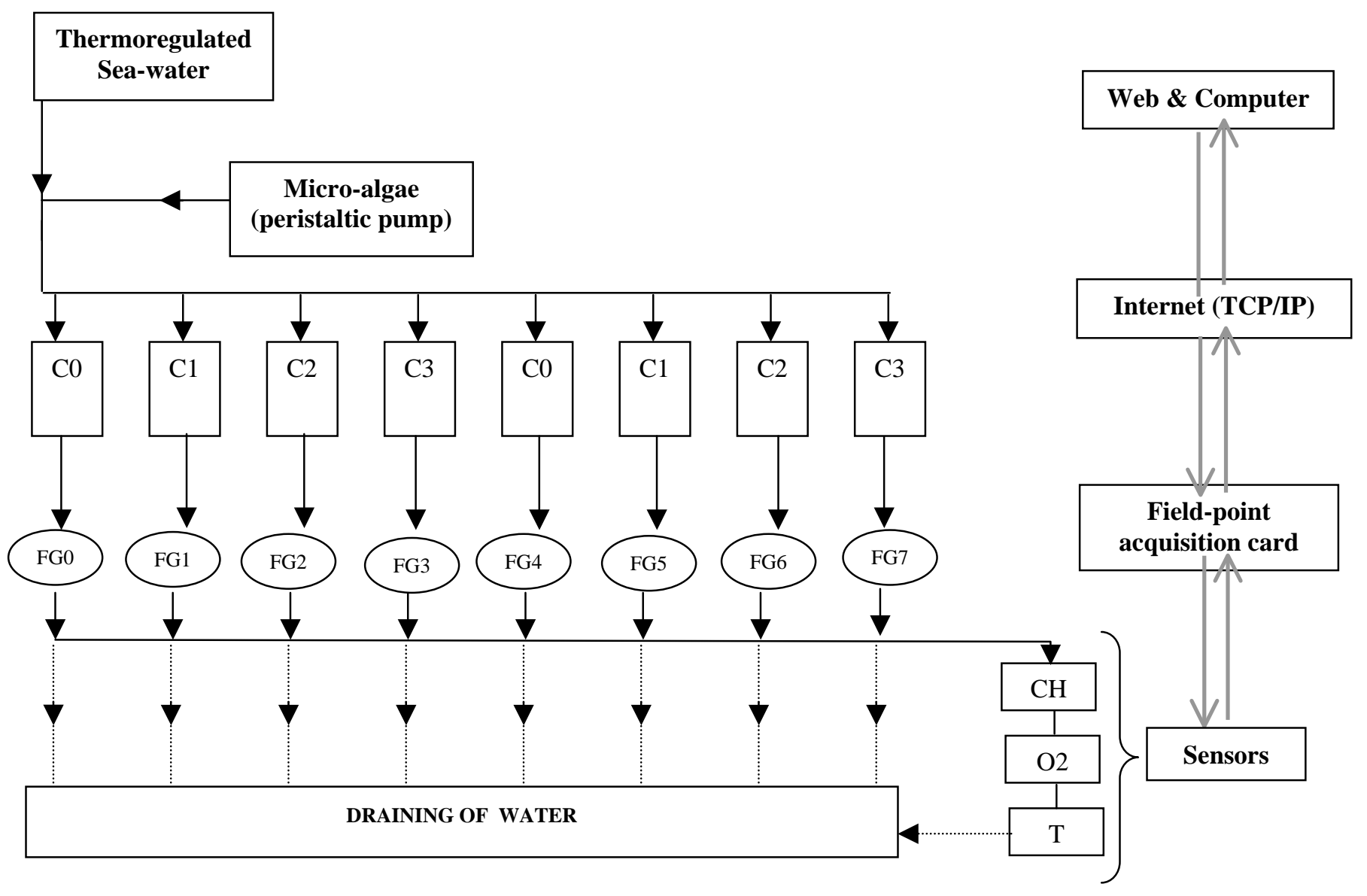

Figure 1

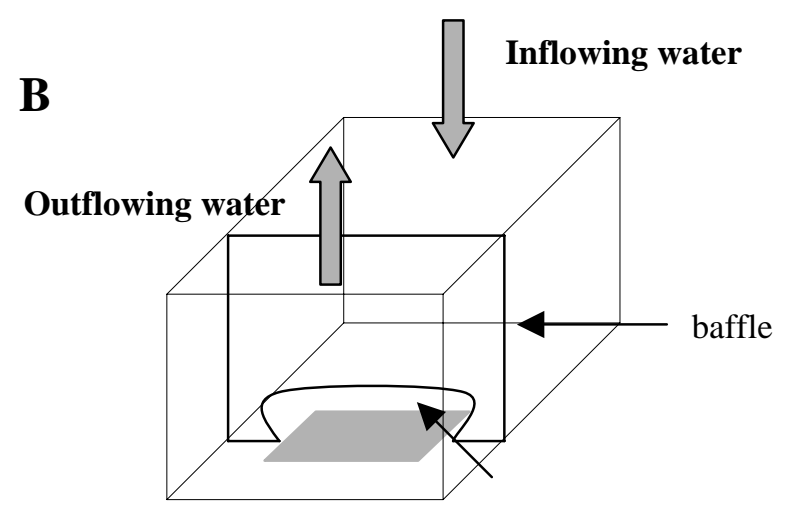



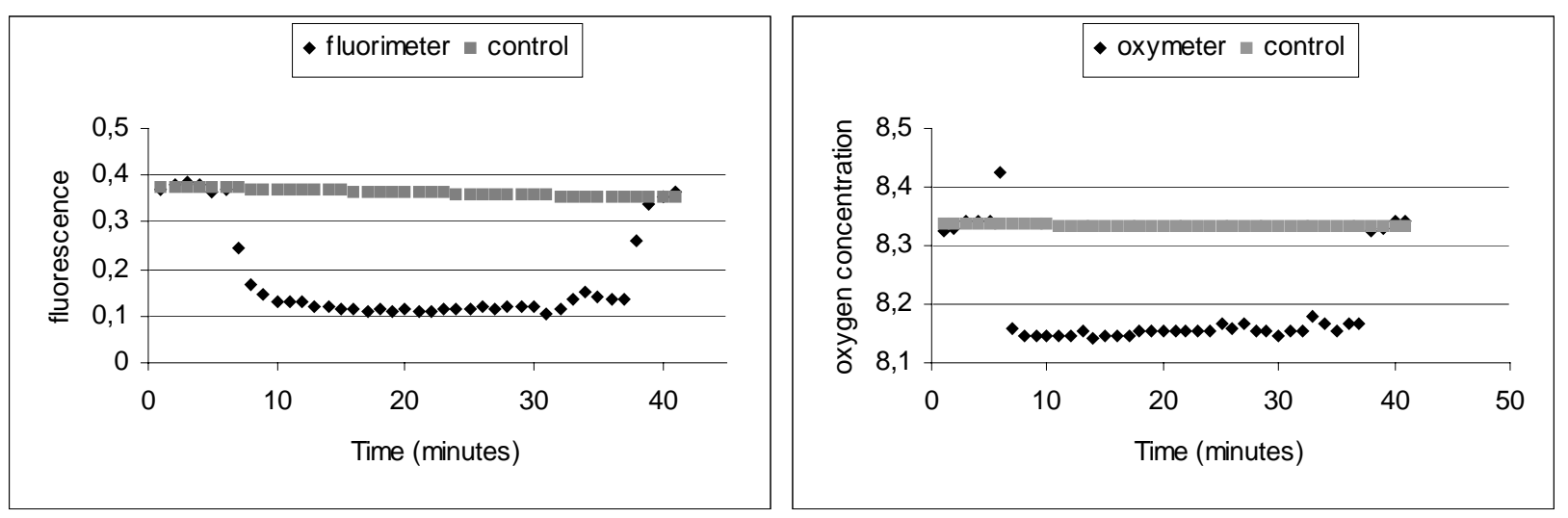

\section{Figure 2}



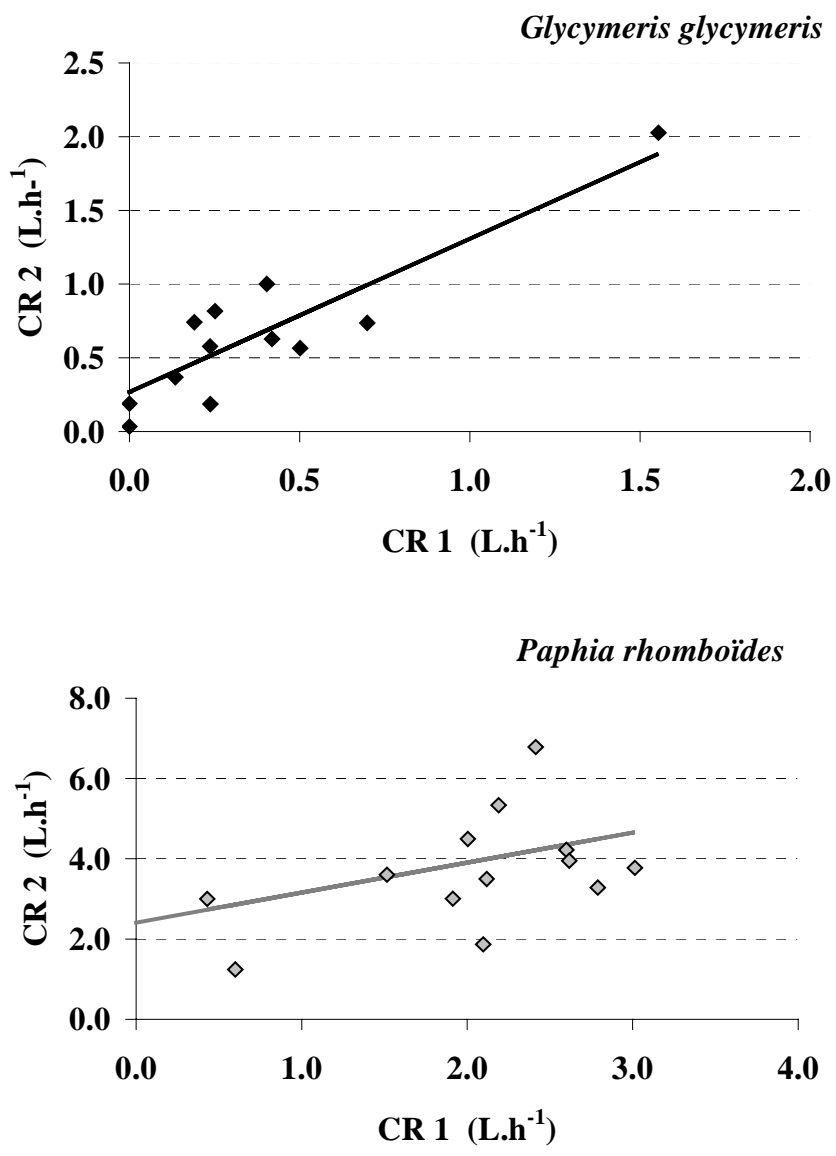

Figure 3 


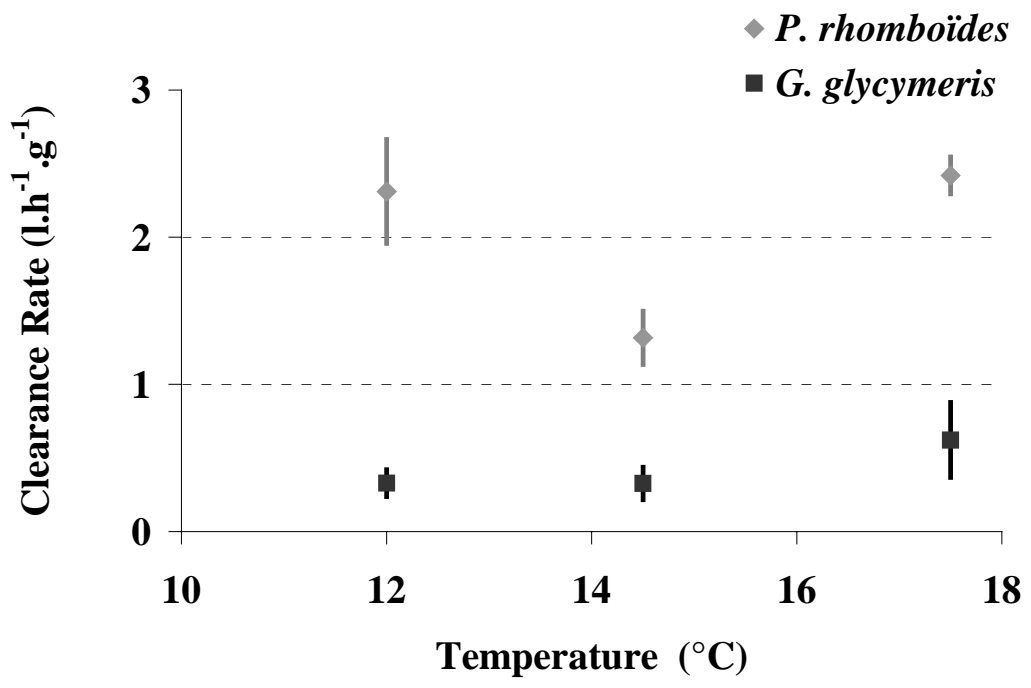

Figure 4 


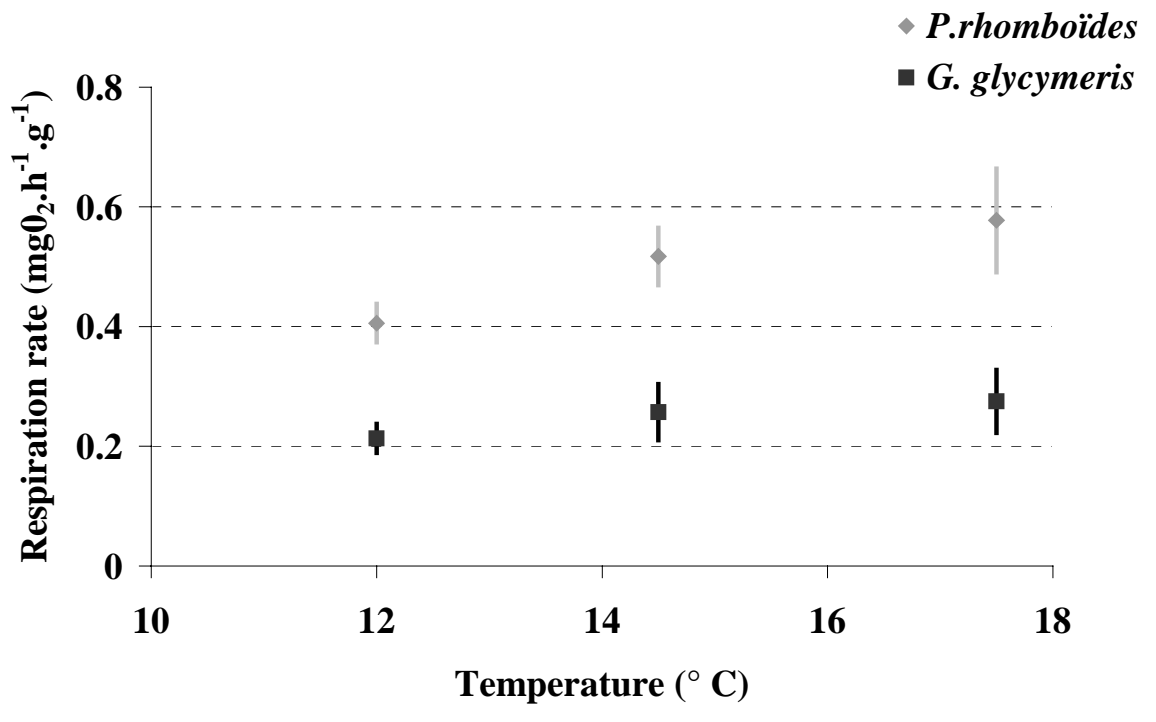

$\underline{\text { Figure } 5}$ 


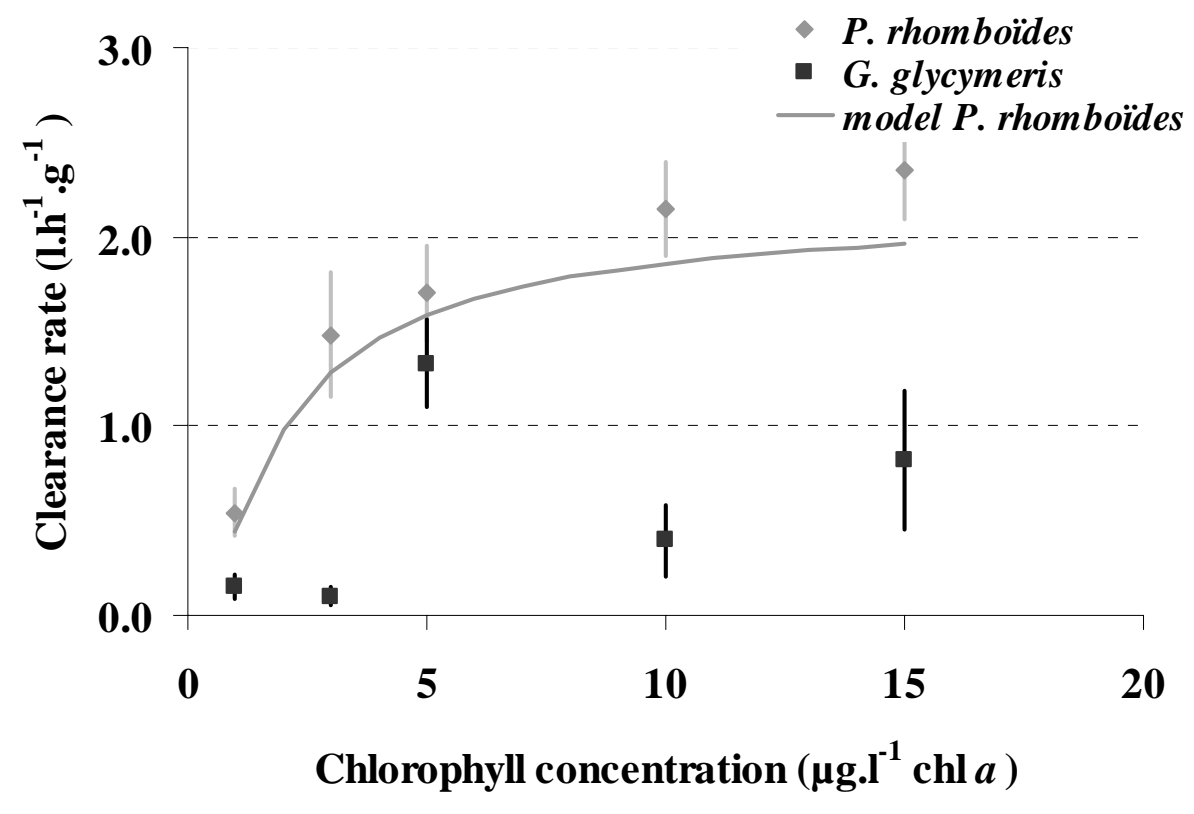

$\underline{\text { Figure } 6}$ 


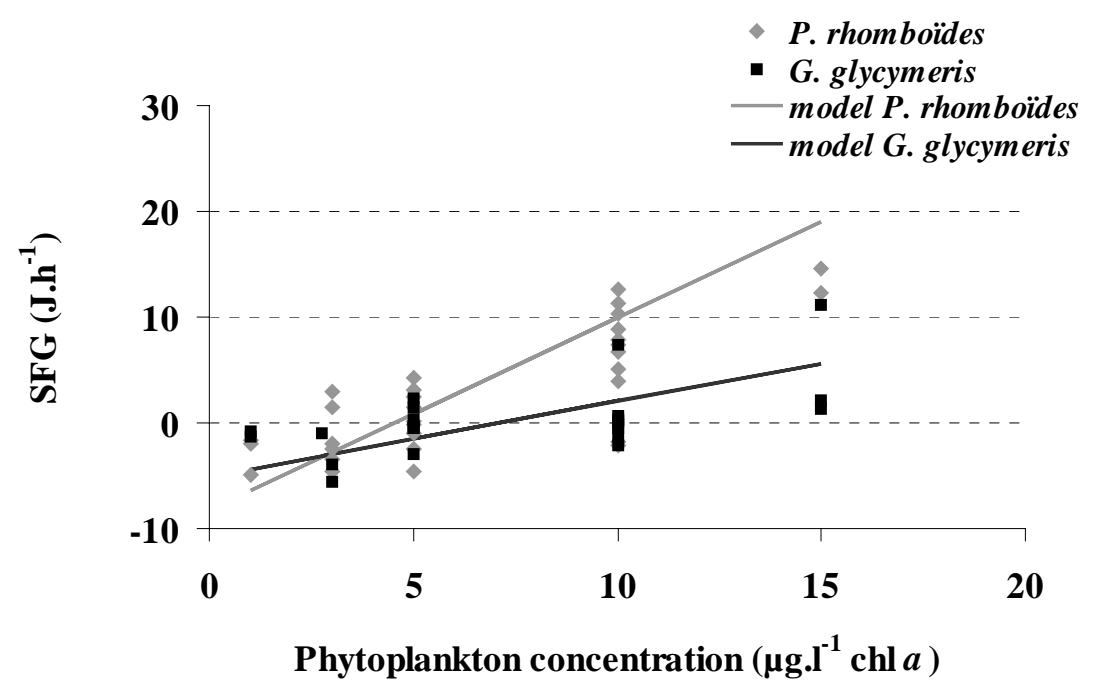

Figure 7 